\title{
11. Hank, My Dad
}

\author{
Michael Nelson
}

Michael Nelson works as a management consultant in Canberra.

Hank Nelson was my dad. I miss him greatly. My family and I are fortunate to have him in his books, documentaries and radio programs, and in our memories. And now in this book we can share the memories of others too.

Dad's public and professional face was expressed through his work. Although I love these fruits of his labour, and will probably enjoy them even more now as a way to connect with Dad, they do not represent what Dad meant to me.

Dad was my teacher. He was a teacher by trade, first high school, then university, but to me he was a teacher of everything. Swimming. High jump. Triple jump. Kicking an Aussie Rules ball. Catching yabbies, and exactly how rotten the meat for bait needed to be. Driving a car and the intricacies of what distance you should leave between your car and the car in front of you when driving on two-way highways. Fixing a bike. Paving. Writing essays. Oiling a cricket bat. The history of just about every town in Victoria and New South Wales. That afternoon tea is the most important meal of the day, closely followed by morning tea. Even a trip to a movie like Beverly Hills Cop starring Eddie Murphy could be educational. 'Mick, the director wants the audience to quickly get into the movie by using upbeat music near the beginning, and then use happy music during the closing credits as we walk out', Dad said, referring to 'Neutron Dance' by the Pointer Sisters and 'Stir it Up' by Patti Labelle.

Dad taught me to play cricket too. He was a good, although careful, batsman. He wasn't much of a bowler. I suspect that combination leads to the opposite blend in the next generation. I was a fast bowler. No matter how busy he was, Dad always found the time to go to 'the nets' with me. Unfortunately for him, when I was playing representative cricket and most wanted to practice in the nets, he was approaching 50 and his reflexes were slowing. Not something a young fast bowler has much sympathy for.

How to get away from sporting events before the rest of the crowd exits was another thing my dad taught me. This skill was most utilised on cold, wintry Friday nights in the 1980s when watching the successful Canberra Cannons basketball team play at 'The Palace'. Leaving with the rest of the crowd meant being stuck in a very cold Mazda 626 waiting for the traffic to disperse. To avoid this, Dad and I would head to the top of the stadium and watch the final few seconds from the top balcony, walking around to the exit that would provide 
the most direct path to the car. As soon as the final buzzer rang, we would sprint to the car, beating the traffic and getting home to a house kept warm by Mum. Dad always seemed so pleased that we were able to avoid the traffic while still seeing the end of the game.

Dad's obsession with getting away quickly from sporting events backfired when we went to see Australia play England in a 1986-87 one-day international cricket match at the SCG. With a couple of overs to go, Australia was well in front. We left our seats on the eastern side of the SCG in the O'Reilly stand and started to make our way around the southern end of the ground, past The Hill. By the time we were halfway around, England needed 17 runs off the final over, with Bruce Reid about to bowl to Allan Lamb. While it was easy to watch the Canberra Cannons from the top of The Palace, it wasn't so easy to watch the cricket from behind screaming fans at the SCG, and we were also competing with about 40,000 spectators rather than 4,000. As we were exiting the SCG we could hear the roar of the crowd as Lamb hit 18 runs off five deliveries. I was there, kind of.

Dad taught me that in all likelihood one or both of my Achilles tendons would break at some point in my life. Dad played a lot of squash when I was young, and eventually he broke an Achilles tendon. This is a fairly common squash injury. Upon recovering, Dad decided to focus on tennis. The incidence of Achilles tendon injuries is lower in tennis than in squash, although with hindsight we can say probably not low enough. He proceeded to break the same Achilles again. This time I got to fully experience his injury. I had to hold my dad's foot in place at the old Canberra Hospital so that a cast could be set with his toes pointing down. They must have been short-staffed that day. From then on every Achilles twinge and pain has filled me with dread. So far, I have avoided breaking my Achilles through a variety of preventative methods - shoes with orthotics, no shoes at all, stretching, strengthening, worrying - and yet the pain and twinges continue. Playing basketball in my middle age may not be the wisest activity.

Dad's teachings were endless. How to cook eggs on toast when I was a teenager, but only because he had malaria; Mum was with him in the hospital, and I was hungry at home. Never to go to a museum with him: he once took 45 minutes to get through the first ten steps of the National Museum of the US Air Force at Wright-Patterson Air Force Base in Dayton, Ohio. In that time I had walked through three hangars of aircraft. Why did they have to put the Pacific Campaign display right at the beginning?

However, of all the things Dad taught me, two stand out. First, he taught me how to appreciate people and see the best in them. Second, he taught me to teach. 
My experience following the death of my father is probably similar to others. I often think I see him, usually in shopping centres. For a split second I think it's him, and then remember it can't be. It's a bit strange, mainly since I don't think he spent that much time in shopping centres. Similarly, I regularly notice things that I think, 'I should talk to Dad about that', and realise I can't. So many things have already happened since his death that he would have been amazed by.

Many of the things I enjoy I now find difficult to do without thinking of Dad and missing him. I can't watch the AFL, cricket or basketball without having conversations with Dad in my head. 'How good is Gary Ablett Jr?' 'Imagine how badly the Australian cricket team would have performed if they hadn't replaced Mickey Arthur with Darren Lehmann?' 'Can Canberra disown James Hird?' 'Tim Duncan deserved to win the NBA title'. These conversations now get lost in the ether.

Fortunately there were other conversations with Dad that haven't been lost. I was lucky to move back to Canberra from Sydney in 2007, which allowed me to spend increased time with him. I was even able to be Dad's chauffeur several times when he had to go to Sydney's Westmead Hospital for his chemotherapy treatments. The goal was to get to Sydney, have the treatment and then get to Berrima in time for lunch, often at the 1834 Surveyor General Inn. We would talk all the way to Sydney and all the way back, about anything and everything. Even the conversations about how the new plants were growing on the M5 median strip, or the fastest route to take to the hospital, were precious.

More recently I've been reminded of emails and letters I received from Dad over my life. More conversations that weren't lost. Dad's emails were like literature, like poetry, and I was rewarded with this prose whenever I emailed him.

How do I want to remember Dad? Trudging around the garden in his gumboots? Looking up from his work papers over his glasses? The way he would curve his tennis serve? Brutally correcting my high school essays? Eating his WeetBix with banana for breakfast while listening to ABC Radio and reading the newspaper and taking up the whole kitchen bench? Playing a delicate late cut? Kicking the footy with him on a small patch of grass outside a country woollen mill while Mum shopped? Watching Mr Bean, The Young Ones, Fawlty Towers, Porridge or Open All Hours? Telling me the background of every player in an AFL match? Most of all I'll remember the way he called me, or rather yelled, 'Mick!' 
This text taken from The Boy from Boort: Remembering Hank Nelson, Edited by Bill Gammage, Brij V. Lal, Gavan Daws, published 2014 by ANU Press, The Australian National University, Canberra, Australia. 